Zagazig Veterinary Journal

Volume 44, Number 2, p. 177-186, September, 2016

OFaculty of Veterinary Medicine, Zagazig University, 44511, Egypt

DOI: 10.21608/zvjz.2016.7860

\title{
Quantitative Developmental Studies on the Otolith of Tilapia nilotica (Oreochromis niloticus) with Reference to Weight and Length \\ Ahmed M. Omar and Hanaa M. El-Ghazali*
}

Anatomy and Embryology Department, Faculty of Veterinary Medicine, Zagazig University, 44511, Egypt

Article History: Received: 25/8/2016 Received in revised form: 10/9/2016 Accepted: 28/9/2016

\begin{abstract}
Owing to the biological and ecological importance of the otolith and the significant role of Tilapia nilotica in aquaculture production, in addition to the less information about the relationships between the size in both otolith and fish individuals, this study was carried out. Forty-five fish specimens of variable length and weight Tilapia nilotica (Oreochromis niloticus) were collected from Al-Abbasa fish farms, Sharkia Governorate, Egypt. The lengths and weights of fish and their otoliths were recorded and the mean as well as the standard deviation were estimated. The different relationships between fish and otolith with regard to length and weight were identified by Pearson correlation coefficients. The means of Tilapia nilotica body weight and otolith weight were $225105.7 \mathrm{mg} \pm 182402.31$ and $55.9743 \mathrm{mg} \pm 32.93714$, respectively. Moreover, the means of fish body length and otolith length were $172.429 \mathrm{~mm} \pm 74.8580$ and $8.1571 \mathrm{~mm} \pm 3.54984$, respectively. In conclusion, there was a positive linear relationship between the developmental rate of fish and otoliths, taking the weights of fish and otoliths in consideration all over this research.
\end{abstract}

Keywords: Sagittal otolith, Tilapia nilotica, Length, Weight

\section{Introduction}

The otolith is an important part of statoacoustic organ (organ of balance and hearing), which is intimately related to the internal ear of fish, where it is known as ear stones or crystals. These crystals are formed from calcium carbonate precipitations and are considered as one of the higher sensory organs such as lateral-line system [1]. The otolith has a biological and ecological importance in species differentiation, age and stocks assessment, individual growth and identification of the diet of predatory fish [213]. The morphology (shape and dimensions) of the otolith was reported to be correlated to the age of fish and ecosystem factors such as geographic location, water depth and environmental qualities for chemical and physical properties [14]. Otolith length, weight, width and volume were related to fish length and species-specific and substantial differences were reported within intimately related species [15]. Fish farming in Egypt reached up to $74 \%$ of total fish production. Tilapias originated from Egypt more than 4000 years ago and they represented $75.5 \%$ of total aquaculture production [16]. The major aquaculture species was the Nile tilapia (Oreochromis niloticus) as reported by FAO
[17]. The otoliths of Tilapia nilotica appeared as cloudy white crystals, located in a deep fossa at the base of the cranial cavity just under the brain, and were in a direct contact with the semicircular canals and sensory hair cells of the internal ear where they were important in the process of balance, hearing and equilibrium [18]. To the best of our knowledge, there were no large scale studies on the development or analysis of otolith-fish size relationship for Tilapia nilotica in Egypt. This study was carried out to fulfill the relationships between the lengths and weights of the otolith and the fish species under investigation.

\section{Material and Methods}

This work was carried out on 45 Tilapia nilotica (Oreochromis niloticus) specimens of variable ages which were collected from AlAbbasa fish farms, Sharkia Governorate, Egypt. Thirty-five fish individuals were used for the detection of the relationships of the otolith length and weight with the body length and weight of fish. Ten fish specimens were examined for the detection of the differences between the various measurements of the right and left otoliths and to evaluate the sex effects on these measurements. 


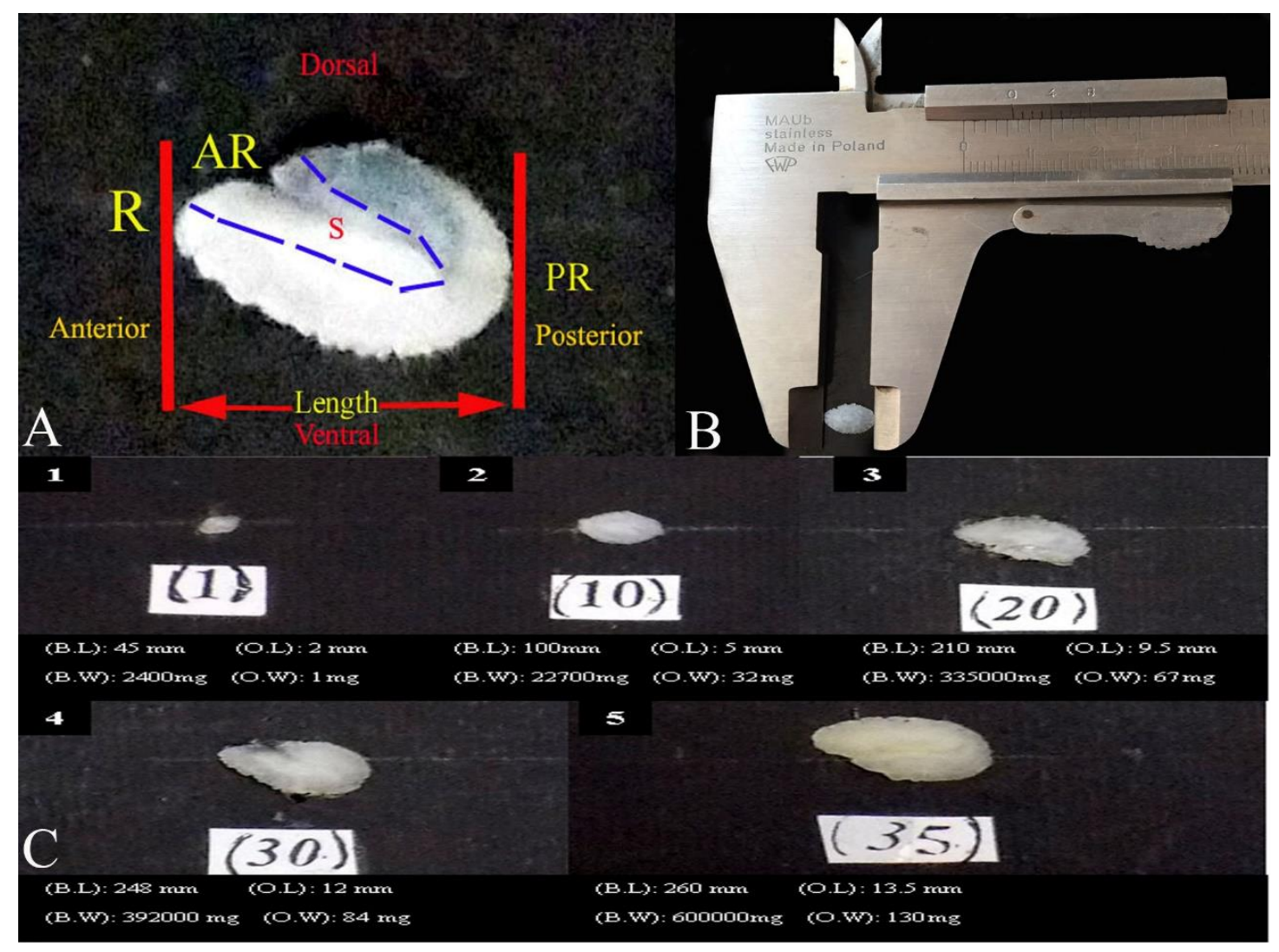

Figure (1): A: a photomacrograph of right sagittal otolith of Tilapia nilotica (medial view) showing the length of the otolith from rostrum (R) to postrostrum (PR) also showing antirostrum (AR), and sulcus (S). B: a photomacrograph of right sagittal otolith of Tilapia nilotica (medial view) measured (in millimeters) using a caliper for detection of the otolith length. $C$ : a photomacrograph of the sagittal otoliths of the examined fish number 1 (1), 10 (2), 20 (3), 30 (4) and 35 (5) showing: the development of the otoliths by increasing in the length and weight.

All specimens were identified and then measured to the nearest millimeters for body length (B.L); measured by the graduated tape from the tip of the snout to the posterior end of the last vertebra (to the beginning of the caudal fin). Also, the total body weight (B.W) (in milligrams) was measured by the digital scale. The sagittal otoliths were removed, cleaned with distilled water and kept dry in the room temperature. The otolith length (O.L) was measured (in millimeters) using a caliper (along the rostrum to the postrostrum axis) (Figures 1A and $\mathrm{B}$ ) according to the nomenclature of Secor et al. [14] and Smale et al. [19]. The otolith weight (O.W) was measured by digital scale.

The data were collected, arranged, summarized and then analyzed using SPSS/PCT system package [20] to detect the mean and standard deviation of length and weight of the fish and otoliths. The relationships of the otolith length and weight with the body length and weight of fish were estimated by using the pearson correlation coefficients by using the following equation:

$$
\mathrm{r}=\frac{\sum X Y-\frac{\sum X \sum Y}{n}}{\sqrt{\left.\left.\sum X 2-\frac{\left(\sum X\right) 2}{n}\right) \sum Y 2-\frac{\left(\sum Y\right) 2}{n}\right)}}
$$


Where:

$\mathrm{r}=$ Pearson correlation coefficient

$\mathrm{X}=$ body weight $(\mathrm{mg})$ or body length $(\mathrm{mm})$

$\mathrm{Y}=$ otolith weight $(\mathrm{mg})$ or otolith length $(\mathrm{mm})$

$\sum=$ summation - sum of all values in range of series
The differences between right and left otoliths were detected by using a paired t-test. The figures of the obtained otoliths of all examined fish (45 individuals) were plotted to show the clear differences in their size and length.

Table 1: The different measurements and the Mean \pm SD of Tilapia nilotica and their otoliths

\begin{tabular}{|c|c|c|c|c|}
\hline Case No. & $\begin{array}{l}\text { Body Length } \\
\text { (B.L) mm }\end{array}$ & $\begin{array}{c}\text { Body Weight } \\
\text { (B.W) mg }\end{array}$ & $\begin{array}{l}\text { Otolith Length } \\
\text { (O.L) mm }\end{array}$ & $\begin{array}{l}\text { Otolith Weight } \\
(\text { O.W }) \mathrm{mg}\end{array}$ \\
\hline 1 & 45 & 2400 & 2 & 1 \\
\hline 2 & 60 & 4200 & 2.6 & 7 \\
\hline 3 & 65 & 8100 & 3 & 9 \\
\hline 4 & 70 & 10500 & 3.5 & 11 \\
\hline 5 & 72 & 10900 & 3.5 & 12 \\
\hline 6 & 75 & 12000 & 4 & 12.5 \\
\hline 7 & 80 & 17300 & 4.3 & 13 \\
\hline 8 & 85 & 20000 & 4.3 & 14.1 \\
\hline 9 & 90 & 21300 & 4.5 & 28 \\
\hline 10 & 100 & 22700 & 5 & 32 \\
\hline 11 & 105 & 25400 & 5.1 & 37 \\
\hline 12 & 115 & 30000 & 5.2 & 40 \\
\hline 13 & 125 & 32900 & 6 & 45 \\
\hline 14 & 150 & 120000 & 7 & 50 \\
\hline 15 & 160 & 170000 & 8 & 53 \\
\hline 16 & 170 & 200000 & 8.5 & 55 \\
\hline 17 & 190 & 250000 & 8.6 & 58 \\
\hline 18 & 200 & 300000 & 9 & 62 \\
\hline 19 & 250 & 320000 & 9.1 & 65 \\
\hline 20 & 210 & 335000 & 9.5 & 67 \\
\hline 21 & 220 & 338000 & 9.6 & 70 \\
\hline 22 & 225 & 340000 & 9.7 & 73 \\
\hline 23 & 230 & 350000 & 10 & 74 \\
\hline 24 & 233 & 300000 & 10 & 76 \\
\hline 25 & 235 & 360000 & 11 & 77 \\
\hline 26 & 240 & 370000 & 11 & 79 \\
\hline 27 & 242 & 375000 & 12 & 79 \\
\hline 28 & 243 & 380000 & 12 & 79.5 \\
\hline 29 & 247 & 384000 & 12 & 80 \\
\hline 30 & 248 & 392000 & 12 & 84 \\
\hline 31 & 248 & 400000 & 12 & 86 \\
\hline 32 & 248 & 437000 & 12 & 89 \\
\hline 33 & 249 & 440000 & 13 & 91 \\
\hline 34 & 250 & 500000 & 13 & 120 \\
\hline 35 & 260 & 600000 & 13.5 & 130 \\
\hline Mean & 172.429 & 225105.7 & 8.1571 & 55.9743 \\
\hline Std. Deviation & 74.8580 & 182402.31 & 3.54984 & 32.93714 \\
\hline
\end{tabular}




\section{Results}

In the current study, the different measurements of fish and otoliths are shown in Table (1). The minimum body weight of Tilapia nilotica was $2400 \mathrm{mg}$ while the maximum body weight measured $600,000 \mathrm{mg}$ with a mean of $225,105.7 \mathrm{mg} \pm 182,402.31$. The minimum otolith weight was one $\mathrm{mg}$ and the maximum was $130 \mathrm{mg}$ with a mean of 55.9743 $\mathrm{mg} \pm 32.93714$. On the other hand, the shortest body length was $45 \mathrm{~mm}$ and the longest was $260 \mathrm{~mm}$ with a mean of $172.429 \mathrm{~mm} \pm 74.8580$. The shortest otolith length was two $\mathrm{mm}$ and the longest was $13.5 \mathrm{~mm}$ with a mean of $8.1571 \mathrm{~mm} \pm 3.54984$ (Table 1).

The interpretation about the different measurements of fish and their otolithic crystals which were examined in this research cleared that, the smallest fish individual of $2400 \mathrm{mg}$ body weight had an otolith of one $\mathrm{mg}$, also the fish measured $45 \mathrm{~mm}$ body length and had an otolith of two mm. In addition, due to the continuous growth and quantitative developmental changes the largest fish individual of $600,000 \mathrm{mg}$ body weight and 260 $\mathrm{mm}$ body length had an otolith of $130 \mathrm{mg}$ in weight and $13.5 \mathrm{~mm}$ in length respectively (Figure 1C).

Positive linear relationships between lengths of fish and otoliths (Figure 2A) and between the weights of fish and otoliths (Figure 2B) were observed. Also, these positive linear relationships were detected between fish length and weight (Figure 2C) and otolith length and weight (Figure 2D). These relationships were statistically significant with a correlation of $0.961,0.979$, 0.963 and 0.970 for body and otolith weight, body and otolith length, body weight and length and otolith weight and length, respectively, with $\mathrm{P}$ value $<0.0001$.
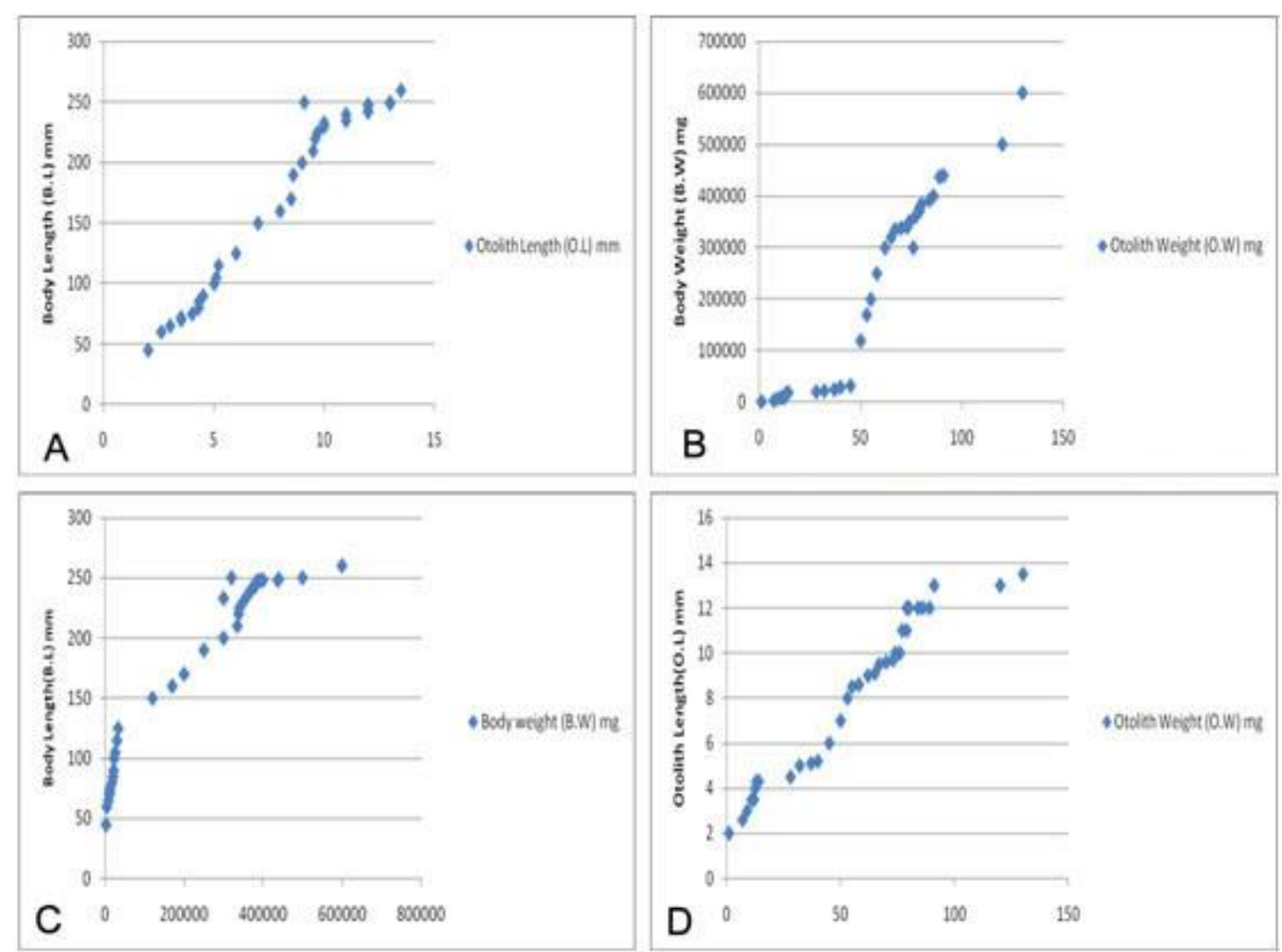

Figure (2): Histograms showing: A: Body length- otolith length relationships in Tilapia nilotica. B: Body weight- otolith weight relationships in Tilapia nilotica. C: Body length- body weight relationships in Tilapia nilotica. D: Otolith length - otolith weight relationships in Tilapia nilotica. 
The present study clarified a good relationship between the weight of otoliths and fish, as well as, the length of both otoliths and fish individuals. Also, the progressive changes in length and weight of fish and their otoliths gave a marked indication about the growth and development of each (Figure 3A). In the present investigation, the mean lengths of the right and left otoliths were 7.6 and $7.5 \mathrm{~mm}$, respectively while the mean weights were 42 and $41 \mathrm{mg}$, respectively. The differences between the measurements (length and weight) of both otoliths were statistically insignificant $(\mathrm{P}>0.05)$ (Figure 3B).

By comparing the measurements of both otolith of male and female fish of the same body weight $(225,000 \mathrm{mg})$. The length of otolith was $7 \mathrm{~mm}$ and the weight was $30 \mathrm{mg}$ (for both otolith) in female, while it was 30 $\mathrm{mm}$ and $40 \mathrm{mg}$ for right and left otoliths of male, respectively (Table 2 and Figure 3C).

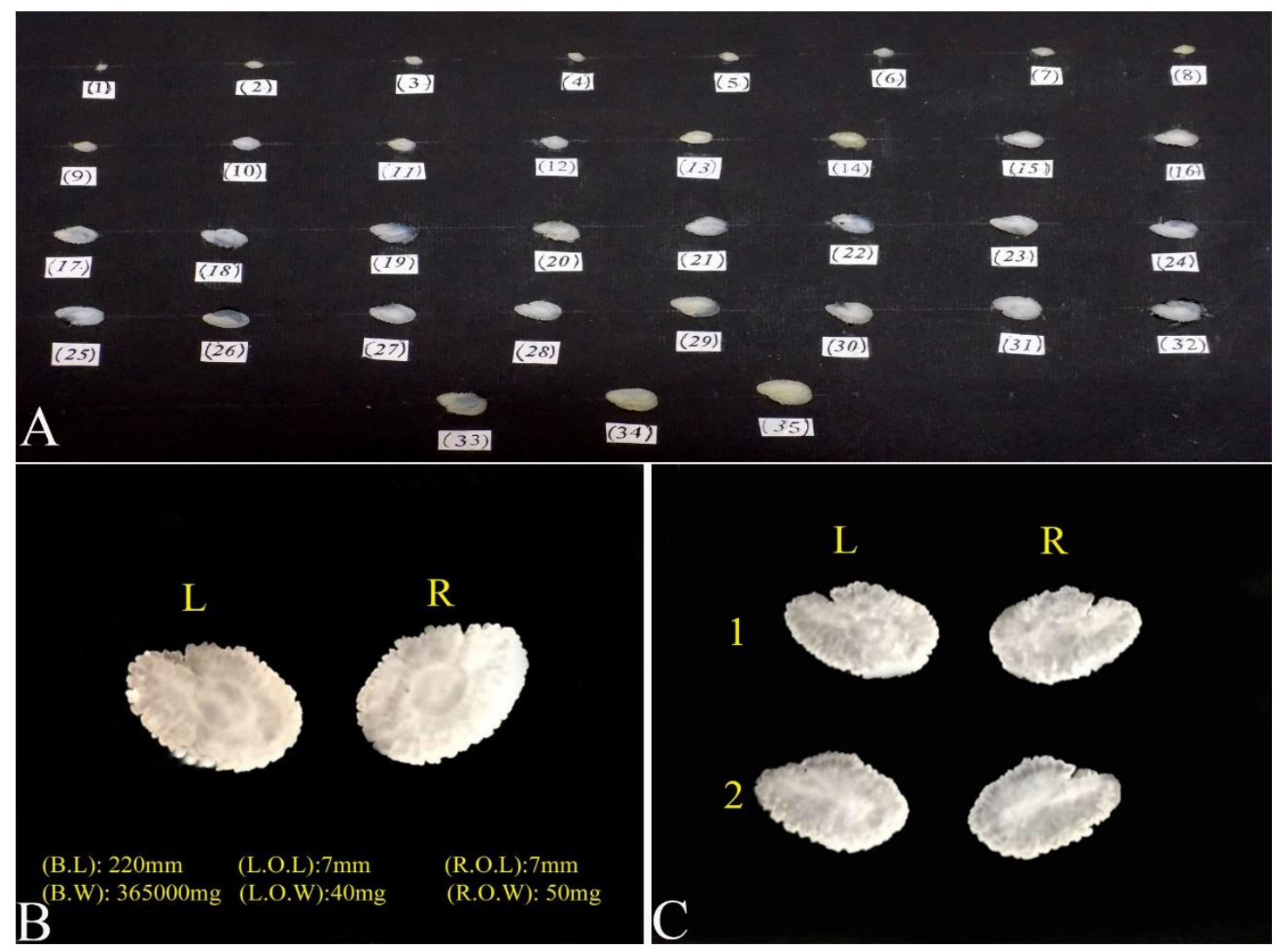

Figure (3): A: a photomacrograph of the sagittal otoliths of the examined fish (35 individuals) showing: the clear differences in their size and lenght. B: a photomacrograph of the sagittal otoliths of the examined fish showing: the insignificant difference between the right $(R)$ and left $(L)$ otoliths (length and weight). C: a photomacrograph of the sagittal otoliths of the examined fish showing: the otoliths of male (1) and the otoliths of female (2) fish had the same body weight and the same otolith length and weight.

\section{Discussion}

Concerning the different measurements of Tilapia nilotica (Oreochromis niloticus), the present study revealed that, the mean body length was $172.429 \mathrm{~mm} \pm 74.8580$ which came in a line with Bwanika et al. [21] who added that the size of $O$. niloticus (of both sexes) captured in Lake Nyamusingiri ranged between 5 and $26 \mathrm{~cm}$. Regarding the relationship between fish length and otolith length, there was linear relationship between the two parameters. Similar findings were recorded by Hunt [15], Morat et al. [22], Longenecker [23] and Jawad et al. [24]. This relationship was clear until the fish reached the greatest size, thereafter the otolith only increased in thickness. The strong linear correlation between fish lengths and otolith lengths was found in younger individuals than 
the older ones $[15,25]$. In fresh water fish, there was a strong relationship between otolith length and fish size [26].

Concerning the effect of age on the otolith length and weight, the results revealed that, whenever the fish increased in length and weight (grown), the otolith increased also in length and weight. These results were in agreement with those of Secor and Dean [27], who reported that, the larger and heavier otoliths were detected in slower growing groups of fish individuals than the faster growing groups. Significant interaction was found between age and fish size that produced an effect on the otolith size.

Table 2: Elucidate the measurements of the right and left otoliths of Tilapia nilotica classified according to sex and the results of paired t-test.

\begin{tabular}{|c|c|c|c|c|c|c|c|}
\hline \multirow[t]{2}{*}{ Number } & \multirow[t]{2}{*}{$\operatorname{sex}$} & \multirow[t]{2}{*}{$\begin{array}{l}\text { Body Length } \\
\text { (B.L) mm }\end{array}$} & \multirow[t]{2}{*}{$\begin{array}{c}\text { Body Weight } \\
\text { (B.W) mg }\end{array}$} & \multicolumn{2}{|c|}{$\begin{array}{l}\text { Otolith Length } \\
\text { (O.L) mm }\end{array}$} & \multicolumn{2}{|c|}{$\begin{array}{c}\text { Otolith Weight } \\
\text { (O.W) mg }\end{array}$} \\
\hline & & & & Right & Left & Right & Left \\
\hline 1 & Male & 228 & 355000 & 9 & 8 & 50 & 50 \\
\hline 2 & Male & 198 & 275000 & 8 & 7 & 50 & 40 \\
\hline 3 & Male & 190 & 275000 & 7 & 8 & 40 & 40 \\
\hline 4 & Male & 220 & 365000 & 7 & 7 & 50 & 40 \\
\hline 5 & Male & 185 & 225000 & 7 & 7 & 30 & 40 \\
\hline 6 & Male & 202 & 280000 & 7 & 7 & 40 & 40 \\
\hline 7 & Male & 233 & 420000 & 9 & 9 & 50 & 50 \\
\hline 8 & Female & 215 & 325000 & 8 & 8 & 50 & 50 \\
\hline 9 & Male & 175 & 200000 & 7 & 7 & 30 & 30 \\
\hline 10 & Female & 197 & 225000 & 7 & 7 & 30 & 30 \\
\hline Mean & & & & 7.6 & 7.5 & 42 & 41 \\
\hline Std. Deviation & & & & 0.8433 & 0.7071 & 9.189 & 7.379 \\
\hline P value & & & & & & & \\
\hline
\end{tabular}

The development and growth of the otolithic crystals (ear stones) was observed in the present study, where there was a good relationship between the size of each otolith and the size of fish individual. These findings were supported by other studies where the otolith grew as a core in the larvae and increased in size gradually by precipitation of calcareous crystals (Calcium carbonate crystals) [28-30]. The otoliths might be used in the determination of fish age specially in marine fish, while in fresh water fish the scales were used for this purpose [30]. In fresh water fish, scales were not accurate estimators of largemouth bass age relative to otolith sections. Whole otoliths were found to be relatively accurate and precise age predictors. The aging errors associated with whole-otolith aged largemouth bass were not biologically significant [31]. Ageing precision was greater with fin rays and otoliths than scales and negatively related to fish length for all ageing structures [32].
Also, Al-Mamry et al. [33] recorded that, there was a relationship between the otolith size (otolith length, weight and width) and the length and weight of fish, a result which came in a line with the present findings.

The growth of otolith gave an accurate estimation of fish age and provided an easier way for fisheries biologists to estimate the age of fish [15, 34, 35]. These findings concur with our observations in this study where the size of otolith differed and increased according to the size and weight of fish.

The intimately relationship between the size of otolith and that of the fish which was observed during this study, was in agreement with the findings of Al-Mamry et al. [33] and Akin et al. [36] who claimed that, the otolith length and weight could be used to determine the age of fish.

In white seabass fish, the otolith growth could be used for estimating the age, also, the size of otolith and its growth showed high variability which was more significant in fish age determination [37]. 
The observations concerning the differences between the various measurements of the right and left otoliths were statistically insignificant $(\mathrm{P}>0.05)$. These findings were supported by other studies that considered the otolith pair were mirror images of each other [15, 22-24, 38-40]. The difference between the length of the right and left otolith was statistically insignificant $(\mathrm{P}>0.05)$ [41].

Due to the few number of female fish specimens, we decided to exclude these females but the important observations clarified in this study about the male and female fish specimens had the same body weight $(225,000 \mathrm{mg})$, otolith length $(7 \mathrm{~mm})$ and otolith weight $(30 \mathrm{mg})$. These findings are in agreement with the observations of many authors who reported that, the sex difference had statistically non-significant effect on the otolith length $[15,25,42]$. There was no difference between females and males for mean length and weight values ( $t$ test, $\mathrm{P}>0.05$ ) [41].

\section{Conclusion}

There was a good relationship between the weight of otoliths and fish, as well as the length of both otoliths and fish individuals. The advanced changes in length and weight of fish and their otoliths confirmed this relationship and displayed a clear evidence about the growth and development of each. Based on the above, the growth of otolith gave a proper evaluation of fish age, with taking into consideration that the differences between the various measurements of the right and left otoliths were statistically insignificant. Also, no differences between females and males for mean otolith's length and weight were observed.

\section{Conflict of interest}

None of the authors have any conflict of interest to declare.

\section{Acknowledgments}

We thank Dr. El Shimaa M. Roushdy, lecturer of animal breeding and production, Faculty of Veterinary Medicine, Zagazig University, Egypt for helping in statistical analysis of the obtained results in this study and helpful comments on the manuscript.

\section{References}

[1] Harder, A. (1975): Anatomy of fish. $2^{\text {nd }}$ Ed. E.Schweizerbart'sche Verlagsbushhandlung (Nagele U. Obermiller) Stuttgart. Pp. 326-332.

[2] Campana, S.E. (2005): Otolith science entering the 21st century. Mar Freshw Res, 56(5): 485-495.

[3] L'Abee-Lund, J.H. (1988): Otolith shape discriminates between juvenile Atlantic salmon, Salmo salar, and brown trout, Salmo trutta. J Fish Biol, 33(6): 899-903.

[4] Cardinale, M.; Doering-Arjes, P.; Kastowsky, $M$. and Mosegaard, $\mathrm{H}$. (2004): Effects of sex, stock and environment on the shape of known-age Atlantic cod (Gadus morhua) otoliths. Can J Fish Aquat Sci, 61(2): 158-167.

[5] Friendland, K.D. and Reddin, D.G. (1994): Use of otolith morphology in stock discrimination of Atlantic salmon (Salmo salar). Can J Fish Aquat Sci, 51(1): 91-98.

[6] Tracey, S.R.; Lyle, J.M. and Duhamel, G. (2006): Application of elliptical Fourier analysis of otolith form as a tool for stock identification. Fish Res, 77(2):138-147.

[7] Gonzalez-Salas, C. and Lenfant, P. (2007): Interannual variability and intraannual stability of the otolith shape in European anchovy Engraulis encrasicolus (L.) in the Bay of Biscay. J Fish Biol, 70(1): 35-49.

[8] Baillon, N. (1992): Otolithométrie : revue et problèmes. In: Coll. Intern. Tissus durs et âge individuel des vertébrés (Baglinière J.L., Castanet J., Conand F. \& F. Meunier, eds). Bondy (France): Orstom/Inra. pp. 21-52.

[9] Barrett, R.T. and Furness, R.W. (1990): The prey and diving depths of seabirds on Hornøy, North Norway after a decrease in the Barents Sea capelin stocks. Ornis Scand, 21: 179-186.

[10] Martucci, O.; Pietrelli, L. and Consiglio, C. (1993): Fish otoliths as indicators of the cormorant Phalacrocorax carbo diet 
(Aves, Pelecaniformes). Ital J Zool, 60(4): 393-396.

[11] Velando, A. and Freire, J. (1999): Intercolony and seasonal differences in the breeding diet of European shags on the Galician coast (NW Spain). Mar Ecol Prog Ser, 188: 225-236.

[12] Furness, R.W. and Tasker, M.L. (2000): Seabird-fishery interactions: Quantifying the sensitivity of seabirds to reductions in sandeel abundance, and identification of key areas for sensitive seabirds in the North Sea. Mar Ecol Prog Ser, 202: 253264.

[13] Lilliendahl, K. and Solmundsson J. (2006): Feeding ecology of sympatric European shags Phalacrocorax aristotelis and great cormorants P. carbo in Iceland. Mar Biol, 149(4): 979-990.

[14] Secor, D.H.; Dean, J.M. and Laban, E.H. (1992): Position and Morphology of Otolith in Fish. In manual for otolith removal and preparation for microstructural examination. The Electric Power Research Institute and the Belle W. Baruch Institute for Marine Biology and Coastal Research.Pp.7-10.

[15] Hunt, J.J. (1992): Morphological characteristics of otoliths for selected fish in the Northwest Atlantic. J Northw Atl Fish Sci, 13: 63-75.

[16] Shaheen, AA.; Seisay, M. and Nouala, S. (2013): An industry assessment of tilapia farming in Egypt. African Union, International Bureau for Animal Resources (AU-IBAR). pp:1-74.

[17] FAO (2012): Food and Agriculture Organization of the United Nation. FAO yearbook, fisheries and aquaculture Statistics.

[18] Omar, A.; Mervat, M. K. and Helal, A. (2010): Anatomical and biochemical studies on the otolith of Tilapia nilotica. African Association of Veterinary Anatomists, $1^{\text {st }}$ Scientific Conference, Cairo, Egypt.

[19] Smale, M.J.; Warson, G. and Hecht, T. (1995): Otolith atlas of Southern African marine fish. Ichthyological Monographs of the JLB Smith Institute of Ichthyology, 1, pp.1-244.

[20] Foster, J.J. (2001): Data Analysis Using SPSS for Windows: A beginner's Guide. Second edition. London Sage.

[21] Bwanika, G.N.; Makanga, B.; Kizito, Y.; Chapman, L.J. and Balirwa, J. (2004): Observations on the biology of Nile tilapia, Oreochromis niloticus, L., in two Ugandan crater lakes. Afr $\mathrm{j}$ Ecol, 42(s1):93-101.

[22] Morat, F.; Banaru, D.; Merigot, B.; Batjakas, J.E.; Betoulle, S.; Vignon, M.; Lecomte-Finiger, R. and Letourneur, Y. (2008): Relationships between fish length and otolith length for nine teleost fish species from the Mediterranean basin, Kerguelen islands and Pacific Ocean. Cybium 32(3):265-269.

[23] Longenecker, K. (2008): Relationships between otolith size and body size for Hawaiian Reef fish. Pacific science, 62 (4):533-539.

[24] Jawad, L.A.; Ambuali, A.; Al-Mamry, J.M. and Al- Busaidi, H.K. (2011): Relationships between fish length and otolith length, width and weight of the Indian Mackerel Rastrelliger Kanagurta (Cuvier, 1817) collected from the sea of Oman. Ribarstvo, 69(2):51-61.

[25] Aydin, R.; Calta, M.; Sen, D. and Coban, M.Z. (2004): Relationships between fish lengths and otolith length in the population of chondrostoma regium (Heckel, 1843) inhabiting Keban Dam Lake. Pak J Biol Sci, 7(9):1550-1553.

[26] Berra, T. M. and Aday, D. D. (2004): Otolith description and age-and-growth of Kurtus gulliveri from northern Australia. J Fish Biol, 65(2): 354-362

[27] Secor, D.H. and Dean, J.M. (1989): Somatic growth effects on the otolith-fish size relationship in young pond-reared striped bass, Morone saxatilis. Can J Fish Aquat Sci, 46(1):113-121.

[28] Hempel, G. and Trekel, H. (1959): Zum Washtum der Otolithen bei Jungherigen. HelgolWiss Meeresunters, 6: 241-259. 
[29] Reinsch, H. (1968): Unterschiede in den Jahresringen Zwishen rechten und linken otolithen einiger kohler, Pollachius Virens, L.Ber.dt.Wiss Komm Meeresforsch, 19: 291-294.

[30] Schmidit, W. (1968): Vergleichend morphologische studie uber die otolithen mariner Knochen Fische. Arch Fischereiwiss, 19(1):1-96.

[31] Besler, D. A. (1999): Utility of Scales and Whole Otoliths for Aging Largemouth Bass in North Carolina. In Proceedings of the Annual Conference of Southeast Association of Fish \& Wildlife Agencies,53:119-129.

[32] Zymonas, N.D. and Mcmahon, T.E. (2009): Comparison of pelvic fin rays, scales and otoliths for estimating age and growth of bull trout, Salvelinus confluentus. Fish Manag Ecol, 16(2): $155-164$

[33] Al-Mamry, J.U.; Jawad, L.A.; Al-Busaidi, H.A.; Al-Habsi, S.A. and Al-Rasbi, S.A. (2010): Relationship between fish size and otolith size and weight in Pathypelagic species, Beryx Splendens Lowe, 1834 collected from the Arabian Sea Coasts of Oman. Quad Mus St Nat Livorno, 23:79-84.

[34] Meglofounou, P. (2006): Comparizon of otolith growth and morphology with somatic growth and age in young-of-theyear bluefin Tuna. J Fish Biol, 68(6): 1867-1878.

[35] Artiz, Y.; Gisis, G. and Goldstein, H. (2009): Manual for Fresh Water Fish Otoliths. Isreal Nature and Parks Authority: 3-20.

[36] Akin, T.; Gulnur, M. and Hasan, T. (2011): The use of otolith length and weight measurements in age estimations of three Gobiidae species (Deltentosteus Quadrimaculatus, Gobius niger and Lesueurigobius Friesii). Turk J Zool, 35(6):819-827.

[37] Romo-Curiel, A.E; Sharon, Z.; Oscar, S.; Chugey, A. and Scott, A. (2015): Otolithbased growth estimates and insights into population structure of White Seabass, Atractoscion nobilis, of the Pacific coast of North America. Fish Res, 161:374-383.

[38] Takabayashi, A. and Ohmura-Iwasaki, T. (2003): Functional asymmetry estimated by measurements of otolith in fish. Biol Sci Space, 17(4):293-297.

[39] lkyaz, A.T.; Metin, G. and Kinacigil, H.T. (2010): The use of otolith length and weight measurements in age estimations of three Gobiidae species (Deltentosteus quadrimaculatus, Gobius niger, and Lesueurigobius friesii). Turk J Zool, 35(6):819-827.

[40] Jawad, L.; Sadighzadeh, Z. and AlBusaidi, H. (2012): The relationship between fish length and otolith dimentions of Mugilid fish, Liza Kluzingeri (Day, 1888) collected from the Persian Gulf near Bandar Abbas. Annales Ser His Nat, 22(1). Scientific and Research Center of the Republic of Slovenia

[41] Kontas, S. and Bostanci, D. (2015): Morphological and biometrical characteristics on otolith of Barbus Tauricus Kessler, 1877 on Light and Scanning Electron Microscope. Int J Morphol, 33(4):1380-1385.

[42] Clark, W.G. (1992): Estimation of Halibut body size from otolith size. International Pacific Halibut Commission. Scientific report No. 75. Pp.3-31. 


$$
\begin{aligned}
& \text { دراسات كمية تطورية على اصداف الأذن لأسماك البلطي النيلى مع الاثشارة الى الوزن و الطول }
\end{aligned}
$$

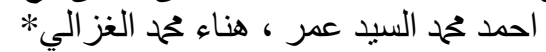

$$
\begin{aligned}
& \text { قسم التشريح والأجنة_ كلية الطب البيطري- جامعة الزئقازيقــ مصر }
\end{aligned}
$$

نظر اللأهمية البيولوجية و الإيكولوجية لأصداف الأذن و الدور الكبير لأسماك البلطي النيلي في انتاج وتربية الاحياء المائية

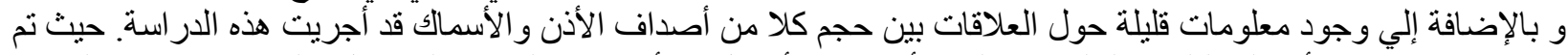

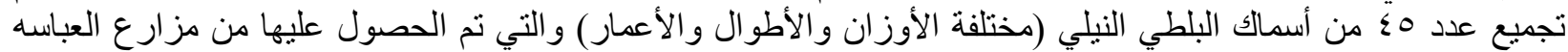

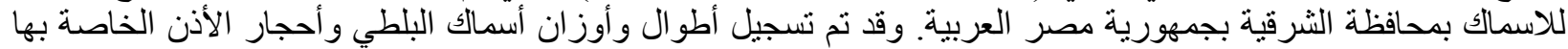

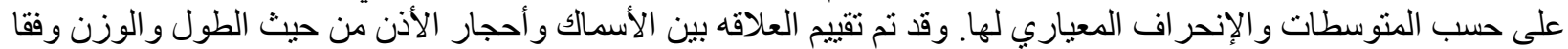

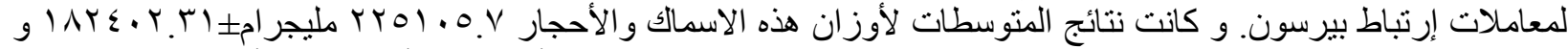

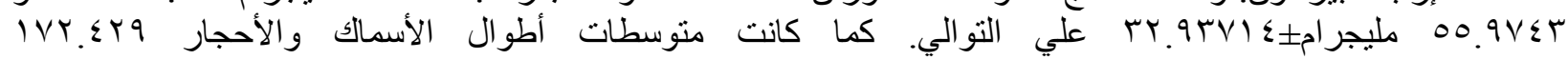

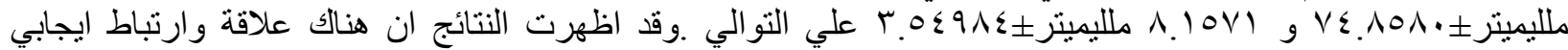
واضح بين نمو الاسمالك ونمو هذه الاصدئ. 